\title{
MOOC INITIATIVE: A TECHNOLOGY ENHANCED LEARNING IN 21 CENTURY AT HIGHER LEARNING INSTITUTIONS
}

\author{
Hafiza Haron ${ }^{1}$ \\ Institute of Malay World and Civilization Universiti Kebangsaan Malaysia (UKM), Malaysia. \\ (Email: afieza.8227@gmail.com) \\ Supyan Hussin ${ }^{2}$ \\ Institute of Malay World and Civilization Universiti Kebangsaan Malaysia (UKM), Malaysia. \\ (Email: supyan@ukm.edu.my)
}

Ahmad Rizal Mohd Yusof ${ }^{3}$

Institute of Ethnic Studies, University Kebangsaan Malaysia (UKM), Malaysia.

(Email: army@ukm.edu.my)

Hafidzan Yusof ${ }^{4}$

Kolej Universiti Poly Tech MARA Kuala Lumpur, Malaysia.

(Email: hafidzan@kuptm.edu.my)

Received date: 22-06-2019

Revised date: 04-09-2019

Accepted date: 06-09-2019

Published date: 12-09-2019

To cite this document: Haron, H., Hussin, S., Yusof, A. R. M., \& Yusof, H. (2019). MOOC Initiative: A Technology Enhanced Learning in 21 Century at Higher Learning Institution. Journal of Information System and Technology Management, 4(14), 26-33.

DOI: $10.35631 /$ jistm.414003

\begin{abstract}
Learning is a medium which is commonly implemented to provide learning module between instructor and learner through distance. In this era of digital technology, learning should be simplified, practical and can be provided in a holistic manner. eLearning is costeffective as compared to traditional forms of learning. The reason for this price reduction is because learning through this mode happens quickly and easily. A lot of training time is reduced with respect to trainers, travel, course materials, and accommodation. Surprisingly, most institutions provide the method of distance learning instead of physical classroom or faceto-face as a modern strategy in the learning environment. But yet, institutions need to prepare all sorts of things in order to take the challenges. In Malaysia, the MOOC initiative has been implemented a few years ago as a blended learning method and continued until now especially in Higher Learning Institutions. The technology of MOOC has sparkling the learning concept into a very interesting medium of learning between learner and instructor. Thus, the Khan eight-dimensional framework has been applied in this study in order to discuss the MOOC initiatives, including the brief history of MOOC, technological structure and learning design as a new technology for enhanced learning in the 21st century and beyond.
\end{abstract}

Keywords: eLearning, Digital Learning, MOOC, Enhanced Learning 


\section{Introduction}

As for now technology has been integrates in most of educational sector such as in secondary and primary school and even in tertiary education. e-Learning plays important roles in today's global sector. e-Learning can be defining as the use of network technology to design, deliver, select, administer and extend the learning (Capper 2010). The process of e-Learning is to deliver instructional resource and sharing opportunities between others. Basically it will take some locations away from places, building or site, to another place by using multimedia elements such as video, audio, texts including all resources like computers, internet and servers. Some people might also call the method as distance learning. By the way, a platform which is being used today known as MOOC become popular especially at higher learning institution. MOOC technology are asynchronous, open-access, Web-based courses geared toward enrolling hundreds or thousands of students at a time. A MOOC brings together people interested in learning (or "students") and an expert or experts who seek to facilitate the learning (Liyanagunawardena et al. 2013). The MOOC methodology is generally known in that it can achieve a wide group of learners (Sadhasivam \& Babu 2017). This study has been conducted to provide a brief justification of MOOC technology in the era of industrial revolution 4.0. The initiatives took place in order to enhanced teaching and learning concept in the digital world.

\section{Literature Review}

\section{History of MOOC}

MOOCs are website that provides free and high quality of educational content to anyone regardless of their physical locations and educational backgrounds. MOOCs represent the final stage in distance education as they offer open educational resources (OER) to students all around the world (Altinpulluk \& Kesim 2016). More than a decade ago, Open Education or Open Educational Resources (OER) has established itself in every corner of the globe by bringing together innovation and technology in online education. Among Open Educational Resources (OER) projects are portal sites, databases, Massive Open Online Courses (MOOC), Open Courseware $(\mathrm{OCW})$, open textbooks (e-books) and tutorials. Consequently, the term OER was first adopted in the 2002 United Nations Educational Scientific and Cultural Organization (UNESCO) forum (Altinpulluk \& Kesim 2016). The term MOOC was first introduced in 2008 as a recent and widely researched development in the field of distance education, which has emerged as popular mode only in 2012 (Saha \& Halder 2018). MOOC or Massive Open Online Course is an online course which is massively open to everyone and everywhere in a large scale environment. A brief analysis of the concepts underlying the acronym MOOC clarifies (Miguel et al. 2018): massive - represents the breadth and geographical range that these kinds of courses have, since they allow for the registration of a large number of participants; open - courses open to any type of participants representing the democratization of knowledge, without any kind of restriction in both economic and prerequisite terms; online - available in real time, 24 hours a day, provided there exists a web connection; course - refers to the format of the course, which encompasses technology, pedagogy and content.

MOOCs are considered a new phenomenon in Malaysia even the technology has started since 2014 and still continued until now. The National Higher Education Strategic Plan (PSPTN), Ministry of Higher Education (MOHE), refers to a document that translates the direction of national higher education in the future. It focuses on the development of quality human being and intellectual capital harness demographic dividend. With the rapid evolution of various technologies and approaches in online teaching and learning, public universities in Malaysia are continuously moving forward in expanding the potential of their e-learning programmes. 
Thus, public universities in Malaysia currently are being excited in order to make their courses available online to public and be as open as possible. In April 2015 a Ministry of Higher Education has launched the Malaysian Educational Blueprint for Higher Education (20152025). The development process of this blueprint started with a review of the PSPTN with three distinct phases as follow:

1. PHASE 1 - Review of PSPTN (February 2013 to February 2014): The Ministry started off with a comprehensive review of current performance and progress on PSPTN to establish a robust fact base on its strengths and weaknesses.

2. PHASE 2 - Conceptualization of the 10 shifts (March 2014 to September 2014): The Ministry identified 10 shifts that would be needed to take the Malaysian higher education system to the next level.

3. PHASE 3 - Finalization of the Malaysia Education Blueprint (Higher Education) (October 2014 to March 2015).

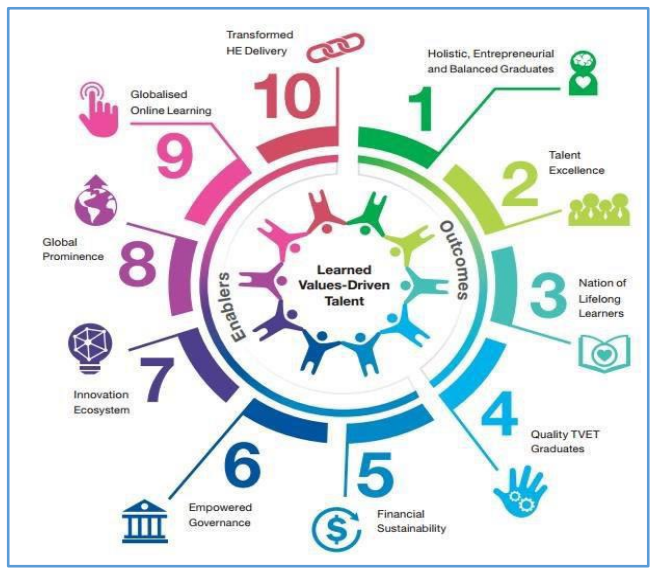

Figure 1: The 10 Shifts

Based from Figure 1, the blueprint has outlines 10 Shifts that will spur continued excellence in the higher education system namely Holistic, Entrepreneurial and Balanced Graduates, Talent Excellence, Nation of Lifelong Learners, Quality Technical Vocational Education and Training (TVET) Graduates, Financial Sustainability, Empowered Governance, Innovation Ecosystem, Global Prominence, Globalised Online Learning and Transformed Higher Education Delivery (PPPM 2015-2025). The year 2015 marks an important historical event in determining the future of the country when the country's higher education plan is launched. It is a transformation of the nation's higher education to enhance excellence in higher education, thereby strengthening Malaysia's existence on the world stage (Utusan Online, 2016).

\section{MOOC Initiatives}

In Malaysia, OpenLearning was chosen as a platform for the MOOC for Public Institutions managed by the Ministry of Higher Education. OpenLearning Solution has created a worldclass MOOC where it is supported by trainers including subject experts, course designers and facilitators. Malaysia had been realizing the advantages of MOOCs as for example, the School of Engineering at Taylor's University was the first institution that offered the MOOCs and the courses that they provide is Entrepreneurship (Al-Shami et al. 2018). Concurrently, for coordination between public universities, Australia-based OpenLearning has partnered with MEIPTA to develop the MOOC portal at public universities. MEIPTA is the Malaysian eLearning Council for Public Universities which coordinates the e-learning activities in all public universities in Malaysia. Since the launch of MOOC, MEIPTA is one of the entities that enthusiastically involved in the development and deployment process. The innovative of MOOC started in 2014 where the four first MOOC take places at their major courses of the 
university programmes. The four pilot of MOOC courses were implemented at Universiti Kebangsaan Malaysia (UKM), Universiti Putra Malaysia (UPM), University Teknologi Malaysia (UiTM) and Universiti Malaysia Sarawak (UNIMAS). Basically the four courses were compulsory course or subject under the university programme. These MOOCs are developed by instructors or lecturers based on the needs set by their institution. But, until now the paper is writing, the courses been applied in MOOC keep continued and growth where majority of public university and even private university now has taken the opportunity of these technology in teaching and learning. Thus, in Malaysia, MOOC is considered a new initiative by the government to boost the technological level of public and private universities (Kumar \& Al-Samarraie 2018).

\section{MOOC Model}

MOOCs concept is based on two pedagogical foundations in education: connectivism and behaviourism (Abu-Shanab \& Musleh 2018). It is relying on how the course has been design or structured. The model can be divided into cMOOC(connectivism) and xMOOC(behaviourism). Connectivist courses, known as cMOOCs where learners are stimulated to active learn in a network through content sharing, creating, and publishing; or extended courses - xMOOCs where courses are well structured and they are an extension to university educational settings (Ivanova 2016). The concept of cMOOC basically to learning conducted by peer, knowledge sharing and searching from others. Meanwhile xMOOC was a course designed by instructor like a traditional classroom converted into online class. xMOOCs are online versions of traditional learning formats applying a knowledge transmission model using video recordings of classroom lectures or custom-produced mini-lectures (Kocdar et al. 2017). By the way, the cMOOCs are the older type or model, as developed by Siemens (Kay et al. 2013). Basically, the courses in MOOC which is conducted at Higher Learning institution were in the category of xMOOC. To compare them: cMOOCs focus on knowledge creation and generation whereas XMOOCs focus on knowledge duplication (Sammour et al. 2016).

\section{Methodology}

\section{MOOC e-Learning Framework}

In this study, the e-Learning framework from Khan eight-dimensional framework has been used to provide a clear picture regarding a few aspects. The framework mainly focusses in the area of infrastructures, technical, pedagogical and instructional design of learning and teaching in e-learning environments as shown in Figure 2.

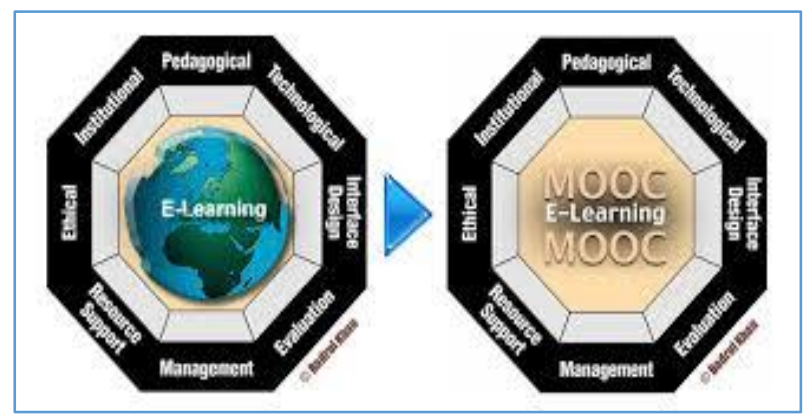

Figure 2: e-Learning Framework relate to MOOC

The figure shown that e-learning might take into consideration of eight factors or dimensions which support meaningful learning environment through online. Moreover, all factors are related to each other and systematically depends with. The systematic emphasis on these factors can help us in creating a meaningful virtual learning environment which involves eight 
dimensions. These eight dimensions could lead the MOOC e-learning environment in order to distribute learning at massive.

To design a learning system in a massive environment, which is also openness and sometimes free to anybody is very challenging. As MOOCs are delivered through an open and distributed e-learning environment so the design, development, implementation, and evaluation of open and distributed learning systems, require a thoughtful analysis and investigation of how to use the attributes and resources of the Internet and digital technologies in concert with instructional (Khan 2010). The Khan eight-dimensional framework encompasses various online learning issues, including: pedagogical, technological, institutional, interface design, evaluation, management, resource support and ethical.

Table 1 illustrate the eight-dimensional framework of e-learning in the context of MOOC. It would suggest and recommend higher institution to take into consideration regarding these frameworks in order to keep MOOC success in the future and to act as leading platform at globalise environment. Furthermore, the framework can be used to ensure that no important factor is omitted from the design of e-learning, whatever its scope or complexity.

Table 1: Khan Eight-Dimensional Framework

\begin{tabular}{|l|l|}
\hline Dimension & Description \\
\hline Pedagogical & $\begin{array}{l}\text { refers to teaching and learning where addresses } \\
\text { issues concerning content analysis, audience } \\
\text { analysis, goal analysis, media analysis, design } \\
\text { approach }\end{array}$ \\
\hline Technological & $\begin{array}{l}\text { examines issues of MOOCs' technology } \\
\text { infrastructure, hardware, and software. }\end{array}$ \\
\hline Institutional & $\begin{array}{l}\text { concerned with issues of administrative affairs, } \\
\text { academic affairs, and student services related } \\
\text { to e-learning. }\end{array}$ \\
\hline Management & $\begin{array}{l}\text { refers to the maintenance of the learning } \\
\text { environment and its global large-scale } \\
\text { distribution. }\end{array}$ \\
\hline $\begin{array}{l}\text { Resource } \\
\text { Support }\end{array}$ & $\begin{array}{l}\text { examines the online support and resources } \\
\text { required to foster meaningful learning } \\
\text { environments. }\end{array}$ \\
\hline Ethical & $\begin{array}{l}\text { relate to social and political influence, cultural } \\
\text { diversity, bias, geographical diversity, learner } \\
\text { diversity, information accessibility, etiquette, } \\
\text { and legal issues. }\end{array}$ \\
\hline $\begin{array}{l}\text { Interface } \\
\text { Design }\end{array}$ & $\begin{array}{l}\text { encompasses page and site design, content } \\
\text { design, navigation, and usability testing }\end{array}$ \\
\hline Evaluation & $\begin{array}{l}\text { refers to both assessments of learners and } \\
\text { evaluation of MOOC environments. }\end{array}$ \\
\hline
\end{tabular}

Sources: e-Learning: Open Learning Environment (Badrul Huda Khan, 2017) 


\section{Discussion}

\section{Blended learning and Self-directed Learning}

At the first initiative at Malaysia, MOOC has been implemented as blended learning where it is the mix up between face-to-face and online method of teaching and learning. The online content mix the concept of learning up to $80 \%$ while the face-to-face environment still remain. Students can access material such as text, video and audio as the instructor upload the material online. As to enhance and foster students understanding in the subject matter, technology has been fully utilized to this environment. In the context of MOOC, this platform will provide opportunity to the traditional classroom become effectiveness, flexibility, efficiency and costeffective. In addition to the apparent advantage of broader access to potentially high quality instruction and instructional material, some believe a MOOC can help revolutionize higher education pedagogy (Canbek 2015). Moreover, MOOC can cover all learning styles that new generation needs in today's learning. Generally, research also has found that blended learning results in improvement in student success and satisfaction, as well as an improvement in students' sense of community when compared with face-to-face courses (Dziuban et al. 2018). Although with the assist of technology, instructor and learners required a skill to conduct a learning at MOOC. As for example learners required high motivation as MOOC used selfdirected learning concept. For instance, learners are able to accomplish the activities on their own, able to follow the course at their own pace and able to use additional resources to improve their understandings on the subject matter. Self-regulation explains how learners manage their learning by actively setting goals, planning to archive their goals, identifying and using resources, monitoring their progresses and using self-corrective measures (Habibah et al. 2016). As the claim that MOOC targets a "massive" audience, so it will require different learning designs compared to small scale university courses. Because of MOOC is free (anyone with an Internet connection can enrol), offers no accreditation and targeting large audiences, instructor or lecturer cannot possibly offer personalized learning or one-to-one supports. Hafizah Ahmad Bakri (n.d.) stating that the learning helped computers have created virtual universities that are increasingly popular today. This virtual university provides course modules as well as interpersonal communication that only requires students to have selfdirected learning capabilities. Hence, MOOC could be applying in this context.

MOOC or Massive Open Online Course are a comparatively contemporary phenomenon in online education. MOOCs represent a powerful force for change on traditional university curriculum, teaching practices and the university system as a whole into online. MOOC also may impact society in multiple ways especially in teaching and learning. MOOC not even used at higher learning institution, MOOC also capable to others who needs a training on certain courses. For example, companies with a worldwide presence can offer courses for employees across various countries. The costs of bringing learners together from different continents is prohibitively expensive for traditional classroom training, whereas many MOOCs offer interactive modes for online discussion among course participants, no matter where they are located (Ong \& Jambulingam 2016). Thus, make a MOOC very reachable. Other than that, MOOC would also cost-effective, convenience and complementary. As such the guidelines of eight-dimensional framework could be an instrument of the organization or institution to provide the best learning environment in massive.

\section{Conclusion and Future Enhancement}

The current trend in teaching and learning has shown that many higher education institutions around the world have digitized their courses' content and assessment which to be used in the teaching and learning process. As MOOC phenomenon are rapidly growth, these platforms would be the future on online education trend in this century onwards. But anyway, the 
framework that has been proposed in this study could provide organizations and especially higher learning institution to design better learning environment at a massive scale in order to bring learners to successful method of e-learning. For future enhancement, the proposed framework could be extending which is a research on each dimensions and sub dimension could be done with one issues or more. Other than that, a research in term of the MOOC usage, the technology acceptance of MOOC could also be conducted as well as the area of instructional design of MOOC.

\section{References}

Abu-Shanab, E. A. \& Musleh, S. 2018. The Adoption of Massive Open Online Courses. International Journal of Web-Based Learning and Teaching Technologies 13(4): 6276. doi:10.4018/ijwltt.2018100104

Al-Shami, S. A., Sedik, S., Rashid, N. \& Hussin, H. 2018. An empirical analysis of MOOC adoption from the perspective of institutional theory. Journal of Advanced Research in Dynamical and Control Systems 10(6 Special Issue): 332-343.

Altinpulluk, H. \& Kesim, M. 2016. The evolution of MOOCs and a clarification of terminology through literature review. EDEN European Distance and E-Learning Network (2015): 220-231. Retrieved from https://www.researchgate.net/publication/305073765

Canbek, N. G. 2015. EDUCATIONAL INNOVATION IN E-LEARNING : MOOCs and OER Movements in Turkey. GLOKALde 1(January): 19-32. Retrieved from http://www.glokalde.com/pdf/issues/1/Article2.pdf

Capper, J. 2010. E-Learning: Current Status and International Experience Overview of ELearning 1-21.

Dziuban, C., Graham, C. R., Moskal, P. D., Norberg, A. \& Sicilia, N. 2018. Blended learning: the new normal and emerging technologies. International Journal of Educational Technology in Higher Education 15(1): 1-16. doi:10.1186/s41239-017-0087-5

Hafizah Ahmad Bakri (n.d.)

Penggunaan Web Pembelajaran Dalam Sistem Pendidikan Di Malaysia. Retrieved from https://www.academia.edu/5389856/PENGGUNAAN_WEB_PEMBELAJARAN_D ALAM_SISTEM_PENDIDIKAN_DI_MALAYSIA

Ivanova, M. 2016. Technology landscape in MOOCs platforms. 2016 19th International Symposium on Electrical Apparatus and Technologies, SIELA 2016. doi:10.1109/SIELA.2016.7543014

Kay, J., Reimann, P., Diebold, E. \& Kummerfeld, B. 2013. MOOCs: So many learners, so much potential. IEEE Intelligent Systems 28(3): 70-77. doi:10.1109/MIS.2013.66

Khan, B. 2010. The Global e-Learning Framework. Stride Handbook $842-51$. Retrieved from http://technologysource.org/article/336/

Kocdar, S., Recep Okur, M. \& Bozkurt, A. 2017. An examination of Xmoocs: An embedded single case study based on Conole'S 12 dimensions. Turkish Online Journal of Distance Education 18(4): 52-65. doi:10.17718/tojde.340381

Kumar, J. A. \& Al-Samarraie, H. 2018. MOOCs in the Malaysian higher education institutions: The instructors' perspectives. Reference Librarian 59(3): 163-177. doi:10.1080/02763877.2018.1458688

Liyanagunawardena, T. R., Adams, A. A., Williams, S. A. \& Rekha Liyanagunawardena, T. 2013. MOOCs: a systematic study of the published literature 2008- 2012. The International Review of Research in Open and Distance Learning 14(3): 202-227. doi:10.3329/bjms.v12i4.16658

Miguel, B., Gonçalves, F. \& Osório, A. J. 2018. Massive Open Online Courses (MOOC) to improve teachers' professional development 1: 52-63. 
Ong, D. \& Jambulingam, M. 2016. Reducing employee learning and development costs: the use of massive open online courses (MOOC). Development and Learning in Organizations 30(5): 18-21. doi:10.1108/DLO-08-2015-0066

Sadhasivam, J. \& Babu, R. 2017. MOOC : A Framework for Learners Using Learning Style. International Education and Research Journal 3(2): 21-24.

Saha, R. \& Halder, U. K. 2018. A Discussion on Massive Open Online Course. Shinjan IV(7): 527-539. Retrieved from www.shinjan.in

Sammour, G., Al-Zoubi, A., Gladun, A., Khala, K. \& Schreurs, J. 2016. MOOCs in universities: Intelligent model for delivering online learning content. 2015 IEEE 7th International Conference on Intelligent Computing and Information Systems, ICICIS 2015 167-171. doi:10.1109/IntelCIS.2015.7397216

Utusan Online (2016) http://www.utusan.com.my/pendidikan/pppm-pt-2015-2025-jadipenentu-1.186044 [Access on 14 April 2019] 